\title{
A Telemedicine Approach to Covid-19 Assessment and Triage
}

\author{
Allison B. Reiss ${ }^{1,2}, * \mathbb{0}$, Joshua De Leon ${ }^{1}$, Isaac P. Dapkins ${ }^{3}$, George Shahin ${ }^{4}$, Morgan R. Peltier ${ }^{2}$ \\ and Eric R. Goldberg ${ }^{5}$ \\ 1 Department of Medicine, NYU Long Island School of Medicine, Mineola, NY 11501, USA; \\ Joshua.DeLeon@NYULangone.org \\ 2 Department of Foundations of Medicine, NYU Long Island School of Medicine, Mineola, NY 11501, USA; \\ Morgan.Peltier@NYULangone.org \\ 3 Department of Population Health and Department of Internal Medicine, NYU Langone Health, New York, \\ NY 10016, USA; Isaac.Dapkins@nyulangone.org \\ 4 Department of Internal Medicine, NYU Langone Health, New York, NY 10016, USA; \\ George.Shahin@nyulangone.org \\ 5 Department of Medicine, NYU Grossman School of Medicine, New York, NY 10016, USA; \\ Eric.Goldberg@nyulangone.org \\ * Correspondence: Allison.Reiss@nyulangone.org; Tel.: +1-516-663-3455
}

Received: 3 August 2020; Accepted: 27 August 2020; Published: 10 September 2020

check for updates

\begin{abstract}
Covid-19 is a new highly contagious RNA viral disease that has caused a global pandemic. Human-to-human transmission occurs primarily through oral and nasal droplets and possibly through the airborne route. The disease may be asymptomatic or the course may be mild with upper respiratory symptoms, moderate with non-life-threatening pneumonia, or severe with pneumonia and acute respiratory distress syndrome. The severe form is associated with significant morbidity and mortality. While patients who are unstable and in acute distress need immediate in-person attention, many patients can be evaluated at home by telemedicine or videoconferencing. The more benign manifestations of Covid-19 may be managed from home to maintain quarantine, thus avoiding spread to other patients and health care workers. This document provides an overview of the clinical presentation of Covid-19, emphasizing telemedicine strategies for assessment and triage of patients. Advantages of the virtual visit during this time of social distancing are highlighted.
\end{abstract}

Keywords: Covid-19; telehealth; pneumonia; cough; novel coronavirus; droplet

\section{Introduction}

Clinical evidence has demonstrated that the Covid-19 virus is easily transmissible from person to person through respiratory droplets from an infected person that are released into the air by sneezing, coughing or talking around other persons [1]. The viral particles can continue to be viable in aerosol form or on surfaces for hours after release [2]. A person's hands may pick up the virus and, through direct contact with one's own nasal mucosa, oral cavity or eyes, potentially lead to self-infection [3]. The highly contagious nature of Covid-19 makes the use of telemedicine particularly advantageous because it circumvents risk of spread by contact. Self-presentation to the emergency department is discouraged unless symptoms are severe. Telemedicine or "healing at a distance" consists of remote delivery of care by health professionals through the use of information and communication technologies and can be used for screening, communication, assessment, counseling and monitoring [4,5].

Telemedicine has been defined by the World Health Organization as "delivery of health care services, where distance is a critical factor, by all health care professionals using information and communication technologies for the exchange of valid information for diagnosis, treatment and 
prevention of disease and injuries, research and evaluation, and for the continuing education of health care providers, all in the interests of advancing the health of individuals and their communities" [6]. It can be accomplished through various platforms in the form of video, audio or text. Telehealth allows large numbers of patients to be assessed while eliminating exposure risk for health care workers [7]. In light of the Covid-19 pandemic, the need for telemedicine to maintain "social distancing" and minimize virus transmission is expected to surge and this creates a need to provide guidance to clinicians who are new to this mode of practice [8-10]. If patients are concerned that they have Covid-19, they can be guided in a video call through a symptom check. Determination of a significant risk should be based on presenting symptoms, history, underlying conditions and community transmission of disease. If it is determined that significant risk is present, then a laboratory test may be ordered.

\section{Covid-19 Presentation}

The spectrum of symptoms in persons infected with Covid-19 ranges from asymptomatic to severe and life-threatening [11-13]. The infection initially may present with a syndrome similar to a common cold or flu with fatigue, dry cough and sometimes fever and over $80 \%$ of patient will have mild, limited disease [14,15]. Acute onset of loss of smell and taste can be presenting symptoms, even before cough and/or fever are noted and may be a useful screening criterion [16-18]. Non-specific symptoms that have been reported include sore throat, nasal congestion, rhinorrhea, and myalgia. In approximately $10 \%$ of cases gastrointestinal symptoms such as loss of appetite, diarrhea, nausea, or vomiting present 1 or 2 days before fever and cough, and virus can be shed in the stool throughout the disease period [19-21]. When presentation is gastrointestinal in nature, diagnosis may be delayed and viral clearance may be slower to occur compared to those with only upper respiratory symptoms [22,23].

Covid-19 is presumed to be infectious 2 to 3 days prior to the onset of symptoms and throughout the course of the illness and infectivity is thought to correspond to detection of virus in nasal, oral and sputum specimens $[24,25]$. Infected individuals who remain asymptomatic may also be able to transmit the virus $[26,27]$.

\section{Criteria for Determining Severity}

Covid-19 severity levels can be categorized as mild, moderate, severe, and critical conditions (Figure 1) [28,29]. Mild disease is defined as patients without dyspnea, without clinical evidence of respiratory distress, no pneumonia on imaging, and blood oxygen saturation maintained above $93 \%$ under resting conditions [30,31]. Fever $\left(<39.1^{\circ} \mathrm{C}\right)$ and cough are seen frequently, even in mild disease. Moderate disease is diagnosed by fever or respiratory symptoms with pneumonia while severe disease manifests as dyspnea and/or hypoxemia. There is respiratory distress with respiratory rate $\geq 30$ breaths/min; $\mathrm{SpO} 2 \leq 93 \%$ at rest, and $\mathrm{PaO} 2 / \mathrm{FIO} 2 \leq 300$ [32]. The most critical patients develop acute respiratory distress syndrome (ARDS) with respiratory failure in need of mechanical ventilation, multiple organ dysfunction (MODS) and/or shock, metabolic acidosis, and coagulation abnormalities that are resistant to treatment $[33,34]$. 


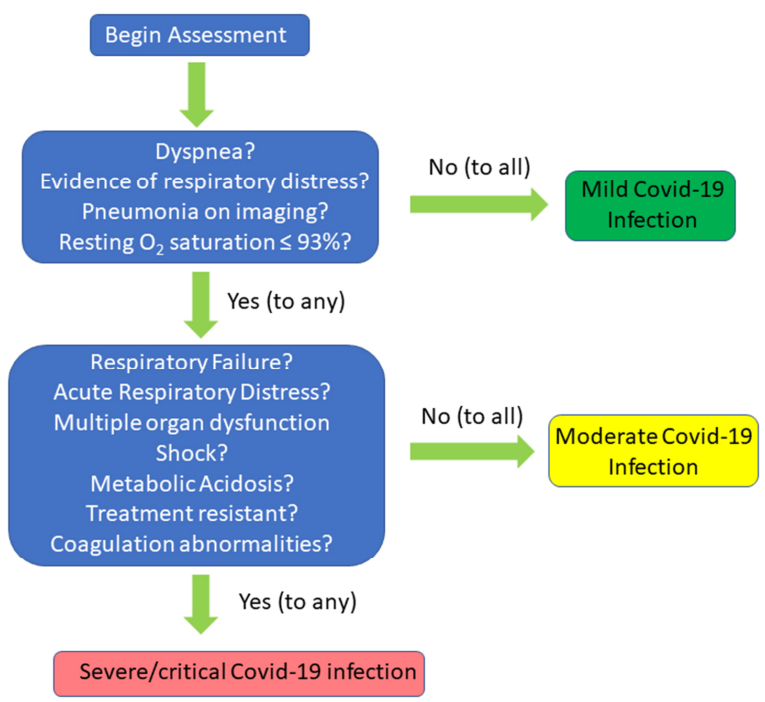

Figure 1. Decision-tree diagram for the classification of severity of Covid-19 infection.

\section{Covid-19 Risk Factors}

Covid-19 disproportionally affects elderly persons and those over the age of 85 are at highest risk of death [35-37] (Figure 2). Infection may spread rapidly among older adults residing in long-term and skilled nursing care facilities and a significant number of Covid-19-related deaths have occurred in residents of these facilities $[38,39]$. Higher mortality rates have been seen in males in multiple countries $[40,41]$.

\section{Risk Factors for More Severe Case of Covid-19}

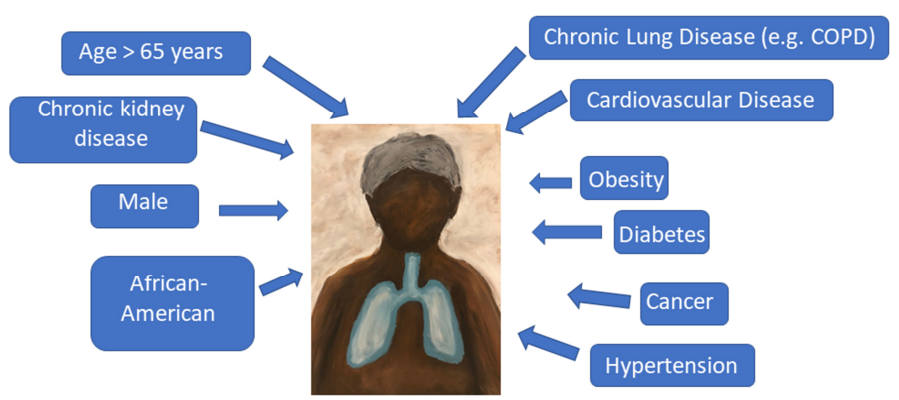

Figure 2. Diagram of risk factors for developing severe Covid-19 infection. COPD, chronic obstructive pulmonary disease.

Preexisting conditions such as diabetes mellitus, cardiovascular disease, hypertension and obesity also increase the risk of death [42-45]. Diabetes and cardiovascular disease are found disproportionately in severe cases of Covid-19 requiring ICU admission [46-49]. Obesity may compromise ventilation at the lung bases and can be considered a state of low grade inflammation and both these factors may contribute to risk of severe Covid-19 infection and greater need for mechanical ventilation in obese patients, especially in patients under age 65 [42,50]. Chronic lung disease and pre-existing chronic obstructive pulmonary disease (COPD) increase the likelihood of developing severe Covid-19 [51-53]. A history of cancer is associated with higher incidence of Covid-19 infection along with elevated risk of severe-associated events [54-56]. 


\section{Laboratory Findings and Imaging}

Reverse-transcription polymerase chain reaction (RT-PCR) of oropharyngeal swab samples from the upper respiratory system is the basis for making a definitive diagnosis of Covid-19. This method amplifies specific segments of the Covid-19 genome, thereby detecting the presence or absence of viral nucleic acid. It is used for screening and as the gold standard for diagnostic purposes [57-59]. However, false negatives can occur so that a negative result does not exclude infection.

Total white blood cell count in early peripheral blood is normal or decreased. The most common laboratory abnormality in Covid-19 patients is lymphopenia, with decrease in lymphocyte count more profound in severe cases [60,61]. Inflammatory markers such as C-reactive protein, ferritin and IL-6 are increased in most patients [62].

Serum sedimentation rates and high sensitivity C-reactive protein are often increased and greater elevations in these markers of inflammation may be associated with disease severity [63-66]. Biochemical test results may show an elevated plasma D-dimer level and D-dimer above $1 \mu \mathrm{g} / \mathrm{L}$ is indicative of hypercoagulability and a poor prognostic indicator [67-72].

Covid-19 pneumonia typically presents on CT scans as a bilateral ground glass appearance, with or without consolidation [73-75]. In Covid-19, lesions are often distributed in peripheral and subpleural areas of the lung [76]. However, the findings are non-specific and may be present in other types of viral pneumonias. The negative predictive value of $C T$ in a multicenter study in China was only $42 \%$, and since in a substantial portion of COVID-19 patients with minimal symptoms a chest CT may be normal, CT is not recommended as a screening tool for Covid-19 [77,78].

\section{The Telemedicine Evaluation}

This section describes, in general terms, the telemedicine evaluation of a potential Covid-19 patient as practiced in the offices of physicians affiliated with a major urban medical center.

\subsection{Initial Screen}

If a patient presents in-person at the office, screening will take place to determine whether the patient can enter the facility. The patient is screened at the door by a screener in full PPE. If the patient screens positive-schedule a virtual visit (same day).

The screener will follow the protocol outlined:

\section{(1) Temperature Check}

Temperature checked at time of arrival for all patients and approved visitors: If $100.0^{\circ} \mathrm{F}$ or greater, patient/visitor is not permitted to enter the clinic and will be instructed to return home (unless in obvious distress) and provided information to schedule a virtual visit. If less than $100.0^{\circ} \mathrm{F}$, proceed to screening questions.

\section{(2) Covid-19 Screening Questions}

Our practice utilizes a set of screening questions (Table 1). Patients are informed that their responses will be kept confidential. Clarification may be needed in cases where patients report symptoms that are not of recent onset and are associated with chronic health conditions. 
Table 1. Covid-19 Screening Questions.

If "Yes" to ANY ONE of the following highest priority questions, the patient is not permitted to enter the clinic.

(1) Have you had a temperature of $100{ }^{\circ} \mathrm{F}$ or greater in the past 7 days?

(2) Have you been diagnosed with Covid-19 in the past 14 days?

(3) Have you had contact with a known confirmed Covid-19 positive person in the last 14 days?

(4) Do you have a cough?

(5) Do you have shortness of breath or difficulty breathing?

If "Yes" to having ANY TWO of the following high priority symptoms in the past 14 days, then the patient is not permitted to enter the clinic. The patient/visitor will be provided with the information to schedule a virtual visit:
(1) Fever
(2) Cough
(3) Repeated shaking with chills
(4) Muscle pain
(5) Headache
(6) Sore throat
(7) New loss of taste or smell

\subsection{Virtual Visit}

\subsubsection{Introduction, Consent, Symptom Check, Demographics}

- Introduction: The physician greets the patient and introduces themselves. The patient's location, name and date of birth are confirmed. The patient is asked whether an interpreter is needed and, if so, an interpreter is provided via a certified interpretation service (conferenced into the call).

- Consent: It is explained to the patient that to provide necessary care the virtual visit will be conducted as a replacement for an onsite visit in order to maintain the patient's safety and the safety of our staff. Verbal consent to proceed with the virtual visit must be obtained. The provider advises the patients of the risks and benefits of the virtual visit. If the patient consents, then the provider documents that the patient understands the risks and benefits of the virtual/telephone visit as discussed and consents to the visit.

- Vital Information-It is helpful if the patient is able to assess their temperature and oxygen saturation. To assess oxygen saturation patients discharged with home oxygen are provided a pulse oximeter at the time of discharge.

- Symptoms-The assessment of the patient's symptoms are based on Centers for Disease Control (CDC) guidelines [79]. This assessment is similar to the assessment done at the time of Covid-19 screening. Key symptoms that raise the index of suspicion for Covid-19 infection is answering "Yes" to ANY ONE of the highest priority questions or ANY TWO of the high priority symptoms in Table 1.

- Assessing clinical stability - it is important to identify patients who need an immediate onsite evaluation at a designated screening center or a hospital emergency department. These are locations where in-person Covid-19 evaluation and testing can take place. The following questions help determine which patients are unstable and need an immediate in-person evaluation:

1. Is the oxygen saturation less than $90 \%$ ?

2. Is the temperature greater than or equal to $102^{\circ} \mathrm{F}$ and not responding to antipyretics?

If symptoms suggest respiratory compromise or hypoxia and the patient is determined to be unstable, then the healthcare provider will instruct the patient to call 911 to go immediately to the emergency department. If the patient is not unstable, but the healthcare provider has determined that an onsite in-person evaluation is warranted, then the patient is referred to a designated screening center. 
- Demographic data-data collected is based on factors that have been shown to be related to a higher incidence and/or severity of Covid-19 disease and must be taken into account in risk assessment as noted below.

Age—greater than 65 are considered "vulnerable"

Sex-males affected greater than females.

Country of origin or race if relevant-endemic areas with high incidence. African-Americans and Hispanics are disproportionately affected.

$0 \quad$ Travel history-pertinent if traveled to an endemic area. Recent travel (within the last 14 days)—Either international travel or travel within the United States, dates of travel, and destination.

6.2.2. The Telemedicine Medical History

- Chief complaint: reason for the visit in the patient's own words.

- History of present illness (HPI): What symptoms are you experiencing and how long have you had these symptoms?

- In addition to the symptoms covered earlier, are you experiencing any of the following?

D Diarrhea

$\bigcirc \quad$ Abdominal pain

○ Nausea or vomiting

- $\quad$ Significant past medical history (PMH) (Table 2)

Table 2. Covid-19 Past Medical History.

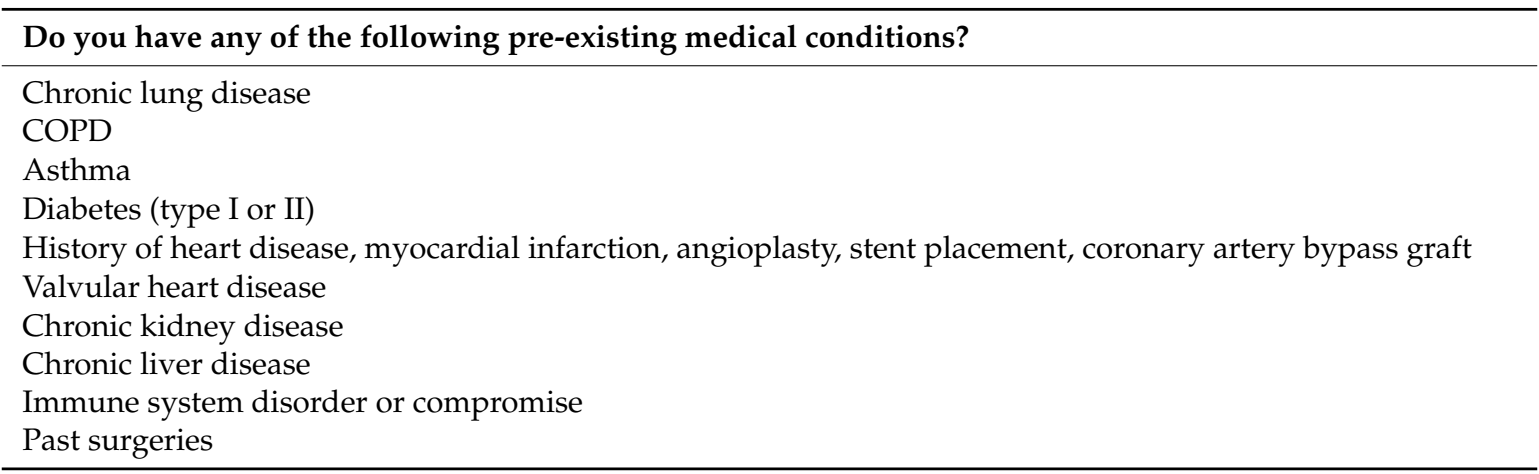

COPD, chronic obstructive pulmonary disease.

- $\quad$ List current medications

- Allergies

- Family history

\subsubsection{The Telemedicine Physical Exam}

The physical exam conducted virtually is patient/caregiver facilitated via video observation (Table 3). The patient or another member of household may take as many vital signs as possible, including temperature, body weight, blood pressure, heart rate. 
Table 3. The Telemedicine Physical Exam.

General. Look for: any apparent distress, toxic/nontoxic appearance

Head. Normocephalic. atraumatic

Eyes. Observe whether extraocular movements are intact; look for scleral icterus

Ears. Appearance of external ears

Throat. Facilitated: oropharyngeal viewing with flashlight

Neck. Observe for full range of motion and midline trachea

Respiratory. Is there distress or use of accessory respiratory muscles?

Abdomen. Facilitated: nondistended and nontender?

Neurologic. Check for alertness without focal deficits, observe gait

Psychologic. Mood and affect; assess for appropriate relation with provider via camera

\section{Laboratory Testing}

Not all patients will require blood tests. However, in the event that a patient requires lab testing it should be available, by appointment. In the follow-up plan, the provider should note that the patient needs to be scheduled for labs. The support staff working with the provider can then contact the patient to schedule an evaluation.

Lab tests relevant for these patients include: complete blood count, comprehensive metabolic panel, D-dimer [67], erythrocyte sedimentation rate [64], C-reactive protein [62], and Covid-19 IgG. Creatine kinase-MB fraction and troponin may also be measured as markers of possible myocardial injury $[80,81]$.

\section{Patients Requiring Self-isolation or Quarantine}

Patients who meet criteria for a diagnosis of Covid-19 infection not requiring emergency medical attention are instructed to go home and self-isolate or self-quarantine.

According to the CDC, isolation separates sick people from people who are not sick while quarantine separates and/or restricts the movement of people who were exposed to a disease. Both are ways to prevent the spread of an infectious disease like Covid-19 [82].

Below are the instructions provided to our patients to protect themselves and others.

\subsection{How to Self-Isolate/Quarantine}

- $\quad$ Stay at home. Take every possible step to reduce going into public spaces. Avoid contact with others. Do not let anyone visit you in your home until your self-isolation/quarantine is over.

- Practice social distancing. If you have to leave your home, practice social distancing. This means trying to maintain a six-foot distance from others. Avoid using any kind of public transportation whenever you can. This includes ridesharing services and taxis.

- Practice good hygiene. Always cover your nose and mouth when you cough or sneeze. Use the crook of your arm (inside your elbow). Do not cough and sneeze into your hand. Wash your hands afterwards.

- Wash your hands. You should be washing your hands often with soap and water for at least $20 \mathrm{~s}$. If soap and water are not available, use an alcohol-based sanitizer. Make sure that it contains at least $60 \%$ alcohol.

- Avoid sharing personal items. Do not share eating utensils and other personal items such as toothbrushes, drinking glasses, and water bottles.

- Clean surfaces. Disinfect surfaces you touch often such as cell phones, doorknobs, light switches, counters, tabletops, etc. Wash your clothes, bath and kitchen towels, clothes you sleep in, bedsheets and pillowcases regularly.

- $\quad$ Rest and drink plenty of fluids to stay hydrated.

- Monitor your health. If you develop any symptoms or they get worse, call your health care provider or make an appointment with your virtual urgent care provider. 


\subsection{If You are Having Any Symptoms Such as Fever or Cough Follow These Additional Instructions:}

- If there is an older adult (over the age of 65) in your home with organ failure, a weakened immune system or uncontrolled diabetes, this person should not share living space with you. If that is not possible, avoid close contact. Have separate sleeping arrangements. Prepare and eat meals separately as well. Use a separate bathroom if possible.

- If you must share a living space with high-risk family members, wear a mask when you are near them. Have as little contact with these people as possible until you no longer have a fever and cough.

- If you must leave your home and you are having any symptoms, wear a face mask, goggles and/or face shield.

\subsection{When Can You Stop Self-Isolation/Quarantine?}

According to CDC guidelines, you can stop self-isolation/quarantine if all of the following applies to you:

- You have had no fever for $72 \mathrm{~h}$ (three full days) without the use of fever reducing medicines and

- Other symptoms such as cough or shortness of breath have gotten better or are almost gone and

- At least seven (7) days have passed since you first started having symptoms. Call your healthcare provider with any questions or if you are unsure whether you can stop self-isolation/quarantine

\section{Management}

Mildly symptomatic Covid-19 is a self-limiting illness and management consists of supportive care with rest, fluids, and antipyretics combined with close monitoring for clinical deterioration [83]. There is no safe, effective and proven treatment at this time. An optimal, evidence-based approach to averting a severe inflammatory response is needed and efforts are ongoing to develop a strategy to achieve this [84]. Of course, vaccine development is the highest priority [85].

\section{Limitations of Telemedicine}

The advantages of telemedicine in assessing and managing Covid-19 have been highlighted here, but when deciding whether this approach is the right one for an individual patient, it is important to consider the drawbacks. Telehealth is only possible if the patient has literacy in the modality used for delivery and if the internet or phone connection is of reasonable quality. Bandwidth, software or other technical issues may interfere with data transmission and obstruct visual and/or auditory aspects of communication [86]. This problem may be encountered more commonly in rural areas and in socioeconomic disadvantaged environments with limited access to technology [87]. Privacy and confidentiality may also be an issue for patients using equipment in areas frequented by other household members. Use of headphones by the patient may be helpful, but do not guarantee privacy. Persons with barriers to use of technology such as visual or hearing impairment may require in-person visits, although specialized communication platforms can make telecare feasible in some circumstances [88,89]. Without the in-person encounter, the feeling of a personal connection and establishment of a provider-patient relationship with the key elements of trust and mutual respect is more difficult [90-92].

\section{Conclusions}

Our offices in the New York City area are using live interactive telemedicine during the Covid-19 pandemic to provide medical screening and assessment remotely. The telehealth platform allows for 
delivery of care while maintaining the physical distancing necessary to prevent the spread of this infectious disease [93]. Ultimately, widespread adoption of this technological tool will be determined by formal studies of quality, comparing telehealth versus in-person outcomes. This type of analysis has just begun and early results are promising with indications that telehealth is reaching persons who might have sought no care at all without this option [94,95].

Author Contributions: Conceptualization, A.B.R., J.D.L., and E.R.G.; writing—original draft preparation, A.B.R., M.R.P., I.P.D. and G.S.; writing-review and editing, A.B.R., I.P.D. and G.S.; design of the figures, M.R.P. and J.D.L. All authors have read and agreed to the publication of the manuscript.

Funding: This research received no external funding.

Acknowledgments: The authors would like to thank Matti Hasselmann and Lauren McMahon for bringing this team of clinicians and researchers together on this project. The authors would also like to thank Charles Fuschillo and The Alzheimer's Foundation of America. We thank Robert Buescher and Samantha M. Steiner.

Conflicts of Interest: The authors declare no conflict of interest.

\section{References}

1. Li, Q.; Guan, X.; Wu, P.; Wang, X.; Zhou, L.; Tong, Y.; Ren, R.; Leung, K.S.; Lau, E.H.; Wong, J.Y.; et al. Early transmission dynamics in wuhan, china, of novel coronavirus-infected pneumonia. N. Engl. J. Med. 2020, 382, 1199-1207. [CrossRef]

2. Van Doremalen, N.; Bushmaker, T.; Morris, D.H.; Holbrook, M.G.; Gamble, A.; Williamson, B.N.; Tamin, A.; Harcourt, J.L.; Thornburg, N.J.; Gerber, S.I.; et al. Aerosol and surface stability of SARS-CoV-2 as compared with SARS-CoV-1. N. Engl. J. Med. 2020, 382, 1564-1567. [CrossRef] [PubMed]

3. Krajewska, J.; Krajewski, W.; Zub, K.; Zatoński, T. COVID-19 in otolaryngologist practice: A review of current knowledge. Eur. Arch. Oto Rhino Laryngol. 2020, 277, 1885-1897. [CrossRef] [PubMed]

4. Hailey, D.; Roine, R.; Ohinmaa, A. Systematic review of evidence for the benefits of telemedicine. J. Telemed. Telecare 2002, 8, 1-7. [CrossRef]

5. Zhang, X.-Y.; Zhang, P. Telemedicine in clinical setting. Exp. Ther. Med. 2016, 12, 2405-2407. [CrossRef]

6. WHO. Telemedicine-Opportunities and Developments in Member States, 2nd ed.; WHO Press: Geneva, Switzerland, 2010; Available online: https://www.who.int/goe/publications/goe_telemedicine_2010.pdf (accessed on 8 January 2020).

7. Gutiérrez, J.; Kuperman, E.; Kaboli, P.J. Using telehealth as a tool for rural hospitals in the COVID-19 pandemic response. J. Rural. Health 2020. [CrossRef] [PubMed]

8. Crump, W.J. Telemedicine: Has the time really finally arrived? J. Rural. Health 2020. [CrossRef] [PubMed]

9. Bashshur, R.; Doarn, C.R.; Frenk, J.M.; Kvedar, J.C.; Woolliscroft, J.O. Telemedicine and the COVID-19 pandemic, lessons for the future. Telemed. e-Health 2020, 26, 571-573. [CrossRef]

10. Parmet, W.E.; Sinha, M.S. Covid-19-The law and limits of quarantine. N. Engl. J. Med. 2020, 382 , e28. [CrossRef]

11. Hu, Z.; Song, C.; Xu, C.; Jin, G.; Chen, Y.; Xu, X.; Ma, H.; Chen, W.; Lin, Y.; Zheng, Y.; et al. Clinical characteristics of 24 asymptomatic infections with COVID-19 screened among close contacts in Nanjing, China. Sci. China Life Sci 2020, 63, 706-711. [CrossRef]

12. Guan, W.-J.; Ni, Z.-Y.; Hu, Y.; Liang, W.-H.; Ou, C.-Q.; He, J.-X.; Liu, L.; Shan, H.; Lei, C.-L.; Hui, D.S.; et al. Clinical characteristics of coronavirus disease 2019 in China. N. Engl. J. Med. 2020, 382, 1708-1720. [CrossRef] [PubMed]

13. Wang, D.; Hu, B.; Hu, C.; Zhu, F.; Liu, X.; Zhang, J.; Wang, B.; Xiang, H.; Cheng, Z.; Xiong, Y.; et al. Clinical characteristics of 138 hospitalized patients with 2019 novel coronavirus-infected pneumonia in Wuhan, China. JAMA 2020, 323, 1061. [CrossRef] [PubMed]

14. Chen, N.; Zhou, M.; Dong, X.; Qu, J.; Gong, F.; Han, Y.; Qiu, Y.; Wang, J.; Liu, Y.; Wei, Y.; et al. Epidemiological and clinical characteristics of 99 cases of 2019-novel coronavirus (2019-nCoV) peumonia in Wuhan, China. SSRN Electron. J. 2020, 395, 507-513. [CrossRef]

15. Huang, C.; Wang, Y.; Li, X.; Ren, L.; Zhao, J.; Hu, Y.; Zhang, L.; Fan, G.; Xu, J.; Gu, X.; et al. Clinical features of patients infected with 2019 novel coronavirus in Wuhan, China. Lancet 2020, 395, 497-506. [CrossRef] 
16. Beltran-Corbellini, A.; Chico-García, J.L.; Martínez-Poles, J.; Rodríguez-Jorge, F.; Natera-Villalba, E.; Gómez-Corral, J.; Gómez-López, A.; Monreal, E.; Parra-Díaz, P.; Cortés-Cuevas, J.L.; et al. Acute-onset smell and taste disorders in the context of COVID-19: A pilot multicentre polymerase chain reaction based case-control study. Eur. J. Neurol. 2020. [CrossRef]

17. Heidari, F.; Karimi, E.; Firouzifar, M.; Khamushian, P.; Ansari, R.; Ardehali, M.M. Anosmia as a prominent symptom of COVID-19 infection. Rhinol. J. 2020, 58, 302-303. [CrossRef]

18. Wee, L.E.; Chan, Y.F.Z.; Teo, N.W.Y.; Cherng, B.P.Z.; Thien, S.Y.; Wong, H.M.; Wijaya, L.; Toh, S.T.; Tan, T.T. The role of self-reported olfactory and gustatory dysfunction as a screening criterion for suspected COVID-19. Eur. Arch. Oto Rhino Laryngol. 2020, 277, 1-2. [CrossRef]

19. Henry, B.M.; De Oliveira, M.H.S.; Benoit, J.; Lippi, G. Gastrointestinal symptoms associated with severity of coronavirus disease 2019 (COVID-19): A pooled analysis. Intern. Emerg. Med. 2020, Apr17, 1-3. [CrossRef]

20. Wei, X.S.; Wang, X.; Niu, Y.R.; Ye, L.L.; Peng, W.B.; Wang, Z.H.; Yang, W.B.; Yang, B.H.; Zhang, J.C.; Ma, W.L.; et al. Diarrhea is associated with prolonged symptoms and viral carriage in COVID-19. Clin. Gastroenterol. Hepatol. 2020, 18, 1753-1759. [CrossRef]

21. Xiao, F.; Tang, M.; Zheng, X.; Liu, Y.; Li, X.; Shan, H. Evidence for gastrointestinal infection of SARS-CoV-2. Gastroenterology 2020, 158, 1831-1833.e3. [CrossRef]

22. Han, C.; Duan, C.; Zhang, S.; Spiegel, B.; Shi, H.; Wang, W.; Zhang, L.; Lin, R.; Liu, J.; Ding, Z.; et al. Digestive symptoms in COVID-19 patients with mild disease severity. Am. J. Gastroenterol. 2020, 115, 916-923. [CrossRef] [PubMed]

23. Schmulson, M.; Dávalos, F.; Berumen, J. Beware: Gastrointestinal symptoms can be a manifestation of COVID-19. Rev. Gastroenterol. Mex. 2020, 85, 282-287. [CrossRef] [PubMed]

24. Zou, L.; Ruan, F.; Huang, M.; Liang, L.; Huang, H.; Hong, Z.; Yu, J.; Kang, M.; Song, Y.; Xia, J.; et al. SARS-CoV-2 viral load in upper respiratory specimens of infected patients. N. Engl. J. Med. 2020, 382, 1177-1179. [CrossRef] [PubMed]

25. He, X.; Lau, E.H.Y.; Wu, P.; Deng, X.; Wang, J.; Hao, X.; Lau, Y.C.; Wong, J.Y.; Guan, Y.; Tan, X.; et al. Temporal dynamics in viral shedding and transmissibility of COVID-19. Nat. Med. 2020, 26, 672-675. [CrossRef]

26. Jiang, X.-L.; Zhang, X.-L.; Zhao, X.-N.; Li, C.-B.; Lei, J.; Kou, Z.-Q.; Sun, W.-K.; Hang, Y.; Gao, F.; Ji, S.-X.; et al. Transmission potential of asymptomatic and paucisymptomatic SARS-CoV-2 infections: A three-family cluster study in China. J. Infect. Dis 2020, 22, 1948-1952. [CrossRef]

27. Wu, J.; Liang, J.; Zhou, H.; Peng, F.; Wang, B.; Jiang, W.; Jia, B.; Luo, T. Clinical features and outcomes of asymptomatic cases of SARS-CoV-2 infection. J. Infect. 2020, 81, e102-e103. [CrossRef]

28. Zhang, J.; Wang, X.; Jia, X.; Li, J.; Hu, K.; Chen, G.; Wei, J.; Gong, Z.; Zhou, C.; Yu, H.; et al. Risk factors for disease severity, unimprovement, and mortality in COVID-19 patients in Wuhan, China. Clin. Microbiol. Infect. 2020, 26, 767-772. [CrossRef]

29. Hong, D.; Long, L.; Wang, A.Y.; Lei, Y.; Tang, Y.; Zhao, J.W.; Song, X.; He, Y.; Wen, E.; Zheng, L.; et al. Kidney manifestations of mild, moderate and severe coronavirus disease 2019: A retrospective cohort study. Clin. Kidney J. 2020, 13, 340-346. [CrossRef]

30. Jin, Y.-H.; Cai, L.; Cheng, Z.-S.; Cheng, H.; Deng, T.; Fan, Y.-P.; Fang, C.; Huang, D.; Huang, L.-Q.; Huang, Q.; et al. A rapid advice guideline for the diagnosis and treatment of 2019 novel coronavirus (2019-nCoV) infected pneumonia (standard version). Mil. Med Res. 2020, 7, 1-23. [CrossRef]

31. Duan, J.; Wang, X.; Chi, J.; Chen, H.; Bai, L.; Hu, Q.; Han, X.; Hu, W.; Zhu, L.; Wang, X.; et al. Correlation between the variables collected at admission and progression to severe cases during hospitalization among patients with COVID-19 in Chongqing. J. Med. Virol. 2020, 10. [CrossRef]

32. Chen, G.; Wu, D.; Guo, W.; Cao, Y.; Huang, D.; Wang, H.; Wang, T.; Zhang, X.; Chen, H.; Yu, H.; et al. Clinical and immunological features of severe and moderate coronavirus disease 2019. J. Clin. Investig. 2020, 130, 2620-2629. [CrossRef] [PubMed]

33. Wu, J.; Wu, X.; Zeng, W.; Guo, D.; Fang, Z.; Chen, L.; Huang, H.; Li, C. Chest CT findings in patients with coronavirus disease 2019 and its relationship with clinical features. Investig. Radiol. 2020, 55, $257-261$. [CrossRef] [PubMed]

34. Bhat, R.; Hamid, A.; Kunin, J.R.; Saboo, S.; Batra, K.; Baruah, D.; Bhat, A.P. Chest imaging in patients hospitalized with COVID-19 infection-A case series. Curr. Probl. Diagn. Radiol. 2020, 49, $294-301$. [CrossRef] [PubMed] 
35. Wu, Z.; McGoogan, J.M. Characteristics of and important lessons from the coronavirus disease 2019 (COVID-19) outbreak in China: Summary of a report of 72314 cases from the Chinese Center for Disease Control and Prevention. JAMA 2020, 323, 1239-1242. [CrossRef]

36. Niu, S.; Tian, S.; Lou, J.; Kang, X.; Zhang, L.; Lian, H.; Zhang, J. Clinical characteristics of older patients infected with COVID-19: A descriptive study. Arch. Gerontol. Geriatr. 2020, 89, 104058. [CrossRef]

37. Onder, G.; Rezza, G.; Brusaferro, S. Case-fatality rate and characteristics of patients dying in relation to COVID-19 in Italy. JAMA 2020. [CrossRef]

38. McMichael, T.M.; Currie, D.W.; Clark, S.; Pogosjans, S.; Kay, M.; Schwartz, N.G.; Lewis, J.; Baer, A.; Kawakami, V.; Lukoff, M.D.; et al. Epidemiology of Covid-19 in a long-term care facility in King County, Washington. N. Engl. J. Med. 2020, 382, 2005-2011. [CrossRef]

39. Arons, M.M.; Hatfield, K.M.; Reddy, S.C.; Kimball, A.; James, A.; Jacobs, J.R.; Taylor, J.; Spicer, K.; Bardossy, A.C.; Oakley, L.P.; et al. Presymptomatic SARS-CoV-2 infections and transmission in a skilled nursing facility. N. Engl. J. Med. 2020, 382, 2081-2090. [CrossRef]

40. Borges do Nascimento, I.J.; Cacic, N.; Abdulazeem, H.M.; Von Groote, T.C.; Jayarajah, U.; Weerasekara, I.; Esfahani, M.A.; Civile, V.T.; Marušić, A.; Jerončić, A.; et al. Novel coronavirus infection (COVID-19) in humans: A scoping review and meta-analysis. J. Clin. Med. 2020, 9, 941. [CrossRef]

41. Channappanavar, R.; Fett, C.; Mack, M.; Eyck, P.T.; Meyerholz, D.K.; Perlman, S. Sex-based differences in susceptibility to severe acute respiratory syndrome coronavirus infection. J. Immunol. 2017, 198, 4046-4053. [CrossRef]

42. Simonnet, A.; Chetboun, M.; Poissy, J.; Raverdy, V.; Noulette, J.; Duhamel, A.; Labreuche, J.; Mathieu, D.; Pattou, F.; Jourdain, M.; et al. High prevalence of obesity in severe acute respiratory syndrome Coronavirus-2 (SARS-CoV-2) requiring invasive mechanical ventilation. Obesity 2020, 28, 1195-1199. [CrossRef] [PubMed]

43. Zhou, F.; Yu, T.; Du, R.; Fan, G.; Liu, Y.; Liu, Z.; Xiang, J.; Wang, Y.; Song, B.; Gu, X.; et al. Clinical course and risk factors for mortality of adult inpatients with COVID-19 in Wuhan, China: A retrospective cohort study. Lancet 2020, 395, 1054-1062. [CrossRef]

44. Li, X.; Xu, S.; Yu, M.; Wang, K.; Tao, Y.; Zhou, Y.; Shi, J.; Zhou, M.; Wu, B.; Yang, Z.; et al. Risk factors for severity and mortality in adult COVID-19 inpatients in Wuhan. J. Allergy Clin. Immunol. 2020, 146, 110-118. [CrossRef] [PubMed]

45. Yang, J.; Zheng, Y.; Gou, X.; Pu, K.; Chen, Z.; Guo, Q.; Ji, R.; Wang, H.; Wang, Y.; Zhou, Y.-N. Prevalence of comorbidities and its effects in patients infected with SARS-CoV-2: A systematic review and meta-analysis. Int. J. Infect. Dis. 2020, 94, 91-95. [CrossRef]

46. Shenoy, A.; Ismaily, M.; Bajaj, M. Diabetes and covid-19: A global health challenge. BMJ Open Diabetes Res. Care 2020, 8, e001450. [CrossRef]

47. Smith, A.A.; Fridling, J.; Ibhrahim, D.; Porter, P.S. Identifying patients at greatest risk of mortality due to COVID-19: A New England perspective. West. J. Emerg. Med. 2020, 21, 785-789. [CrossRef]

48. Figliozzi, S.; Masci, P.; Ahmadi, N.; Tondi, L.; Koutli, E.; Aimo, A.; Stamatelopoulos, K.; Dimopoulos, M.; Caforio, A.L.; Georgiopoulos, G. Predictors of adverse prognosis in Covid-19: A systematic review and meta-analysis. Eur. J. Clin. Investig. 2020, 13362. [CrossRef]

49. Butt, N.; Arshid, A.; Ahmad, S.A.; Khalid, N.; Kayani, W.T. Cardiovascular complications in COVID-19. Am. J. Emerg. Med. 2020. [CrossRef]

50. Anderson, M.; Geleris, J.; Anderson, D.; Zucker, J.; Nobel, Y.R.; Freedberg, D.; Small-Saunders, J.; Rajagopalan, K.N.; Greendyk, R.; Chae, S.-R.; et al. Body mass index and risk for intubation or death in SARS-CoV-2 infection. Ann. Intern. Med. 2020. [CrossRef]

51. Atkins, J.L.; Masoli, J.A.H.; Delgado, J.; Pilling, L.C.; Kuo, C.-L.; Kuchel, G.A.; Melzer, D. Preexisting comorbidities predicting COVID-19 and mortality in the UK biobank community cohort. J. Gerontol. Ser. A Boil. Sci. Med. Sci. 2020, 183. [CrossRef]

52. Zhou, Y.; Yang, Q.; Chi, J.; Dong, B.; Lv, W.; Shen, L.; Wang, Y. Comorbidities and the risk of severe or fatal outcomes associated with coronavirus disease 2019: A systematic review and meta-analysis. Int. J. Infect. Dis. 2020. [CrossRef] [PubMed]

53. Emami, A.; Javanmardi, F.; Pirbonyeh, N.; Akbari, A. Prevalence of underlying diseases in hospitalized patients with COVID-19: A systematic review and meta-analysis. Arch. Acad. Emerg. Med. 2020, 8, e35. [PubMed] 
54. Liang, W.; Guan, W.; Chen, R.; Wang, W.; Li, J.; Xu, K.; Li, C.; Ai, Q.; Lu, W.; Liang, H.; et al. Cancer patients in SARS-CoV-2 infection: A nationwide analysis in China. Lancet Oncol. 2020, 21, 335-337. [CrossRef]

55. Van Dam, P.A.; Huizing, M.; Mestach, G.; Dierckxsens, S.; Tjalma, W.; Trinh, X.B.; Papadimitriou, K.; Altintas, S.; Vermorken, J.; Vulstekeb, C.; et al. SARS-CoV-2 and cancer: Are they really partners in crime? Cancer Treat. Rev. 2020, 89, 102068. [CrossRef] [PubMed]

56. Kuderer, N.M.; Choueiri, T.K.; Shah, D.P.; Shyr, Y.; Rubinstein, S.M.; Rivera, D.R.; Shete, S.; Hsu, C.-Y.; Desai, A.; Lopes, G.D.L.; et al. Clinical impact of COVID-19 on patients with cancer (CCC19): A cohort study. Lancet 2020, 395, 1907-1918. [CrossRef]

57. Lippi, G.; Simundic, A.-M.; Plebani, M. Potential preanalytical and analytical vulnerabilities in the laboratory diagnosis of coronavirus disease 2019 (COVID-19). Clin. Chem. Lab. Med. 2020, 58, 1070-1076. [CrossRef]

58. Ravi, N.; Cortade, D.L.; Ng, E.; Wang, S.X. Diagnostics for SARS-CoV-2 detection: A comprehensive review of the FDA-EUA COVID-19 testing landscape. Biosens. Bioelectron. 2020, 165, 112454. [CrossRef]

59. Bustin, S.A.; Nolan, T. RT-qPCR Testing of SARS-CoV-2: A Primer. Int. J. Mol. Sci. 2020, 21, 3004. [CrossRef]

60. Richardson, S.; Hirsch, J.S.; Narasimhan, M.; Crawford, J.M.; McGinn, T.; Davidson, K.W.; Barnaby, D.P.; Becker, L.B.; Chelico, J.D.; Cohen, S.L.; et al. Presenting characteristics, comorbidities, and outcomes among 5700 patients hospitalized with COVID-19 in the New York City area. JAMA 2020, 323, 2052. [CrossRef]

61. Jesenak, M.; Brndiarova, M.; Urbancikova, I.; Rennerova, Z.; Vojtkova, J.; Bobcakova, A.; Ostro, R.; Banovcin, P. Immune parameters and COVID-19 infection-Associations with clinical severity and disease prognosis. Front. Microbiol. 2020, 10, 364. [CrossRef]

62. Cao, W.; Li, T. COVID-19: Towards understanding of pathogenesis. Cell Res. 2020, 30, 367-369. [CrossRef] [PubMed]

63. Qiu, P.; Zhou, Y.; Wang, F.; Wang, H.; Zhang, M.; Pan, X.; Zhao, Q.; Liu, J. Clinical characteristics, laboratory outcome characteristics, comorbidities, and complications of related COVID-19 deceased: A systematic review and meta-analysis. Aging Clin. Exp. Res. 2020, 1-10. [CrossRef]

64. Lapić, I.; Rogić, D.; Plebani, M. Erythrocyte sedimentation rate is associated with severe coronavirus disease 2019 (COVID-19): A pooled analysis. Clin. Chem. Lab. Med. 2020, 58, 1146-1148. [CrossRef] [PubMed]

65. Hou, W.; Zhang, W.; Jin, R.; Liang, L.; Xu, B.; Hu, Z. Risk factors for disease progression in hospitalized patients with COVID-19: A retrospective cohort study. Infect. Dis. 2020, 52, 498-505. [CrossRef] [PubMed]

66. Feng, X.; Li, S.; Sun, Q.; Zhu, J.; Chen, B.; Xiong, M.; Cao, G. Immune-Inflammatory parameters in COVID-19 Cases: A systematic review and meta-analysis. Front. Med. 2020, 7, 301. [CrossRef]

67. Kavsak, P.A.; De Wit, K.; Worster, A. Emerging key laboratory tests for patients with COVID-19. Clin. Biochem. 2020, 81, 13-14. [CrossRef]

68. Zhang, L.; Yan, X.; Fan, Q.; Liu, H.; Liu, X.; Liu, Z.; Zhang, Z. D-dimer levels on admission to predict in-hospital mortality in patients with Covid-19. J. Thromb. Haemost. 2020, 18, 1324-1329. [CrossRef]

69. Ng, J.J.; Choong, A.M. Thromboembolic events in patients with SARS-CoV-2. J. Vasc. Surg. 2020. [CrossRef]

70. Salamanna, F.; Maglio, M.; Landini, M.P.; Fini, M. Platelet functions and activities as potential hematologic parameters related to Coronavirus disease 2019 (Covid-19). Platelets 2020, 2020, 1762852. [CrossRef]

71. Vidali, S.; Morosetti, D.; Cossu, E.; Luisi, M.L.E.; Pancani, S.; Semeraro, V.; Consales, G. D-dimer as an indicator of prognosis in SARS-CoV-2 infection: A systematic review. ERJ Open Res. 2020, 6, 00260-2020. [CrossRef]

72. Oudkerk, M.; Kuijpers, D.; Oudkerk, S.F.; Van Beek, E.J. The vascular nature of COVID-19. Br. J. Radiol. 2020, 20200718. [CrossRef] [PubMed]

73. Liu, M.; Zeng, W.; Wen, Y.; Zheng, Y.; Lv, F.; Xiao, K. COVID-19 pneumonia: CT findings of 122 patients and differentiation from influenza pneumonia. Eur. Radiol. 2020, 1-7. [CrossRef]

74. Zhang, B.; Zhang, J.; Chen, H.; Chen, L.; Chen, Q.; Li, M.; Chen, Z.; You, J.; Yang, K.; Zhang, S. Novel coronavirus disease 2019 (COVID-19): Relationship between chest CT scores and laboratory parameters. Eur. J. Nucl. Med. Mol. Imaging 2020, 47, 1-7. [CrossRef] [PubMed]

75. Awulachew, E.; Diriba, K.; Anja, A.; Getu, E.; Belayneh, F. Computed Tomography (CT) Imaging features of patients with COVID-19: Systematic review and meta-analysis. Radiol. Res. Pr. 2020, 2020, 1023506. [CrossRef] [PubMed]

76. Li, Y.; Xia, L. Coronavirus disease 2019 (COVID-19): Role of chest CT in diagnosis and management. Am. J. Roentgenol. 2020, 214, 1280-1286. [CrossRef] [PubMed] 
77. Guneyli, S.; Atceken, Z.; Dogan, H.; Altinmakas, E.; Atasoy, K.C. Radiological approach to COVID-19 pneumonia with an emphasis on chest CT. Diagn. Interv. Radiol. 2020, 26, 323-332. [CrossRef]

78. Bernheim, A.; Mei, X.; Huang, M.; Yang, Y.; Fayad, Z.A.; Zhang, N.; Diao, K.; Lin, B.; Zhu, X.; Li, K.; et al. Chest CT findings in Coronavirus disease-19 (COVID-19): Relationship to duration of infection. Radiology 2020, 295. [CrossRef]

79. Anonymous. Powassan virus: Centers for disease control and prevention. Prog. Cardiovasc. Dis. 2020, 19, 108.

80. Li, J.-W.; Han, T.-W.; Woodward, M.; Anderson, C.S.; Zhou, H.; Chen, Y.; Neal, B. The impact of 2019 novel coronavirus on heart injury: A systematic review and meta-analysis. Prog. Cardiovasc. Dis. 2020. [CrossRef]

81. Deng, P.; Ke, Z.; Ying, B.; Qiao, B.; Yuan, L. The diagnostic and prognostic role of myocardial injury biomarkers in hospitalized patients with COVID-19. Clin. Chim. Acta 2020, 510, 186-190. [CrossRef]

82. Wilder-Smith, A.; Freedman, D.O. Isolation, quarantine, social distancing and community containment: Pivotal role for old-style public health measures in the novel coronavirus (2019-nCoV) outbreak. J. Travel Med. 2020, 27, taaa020. [CrossRef] [PubMed]

83. Bajwah, S.; Wilcock, A.; Towers, R.; Costantini, M.; Bausewein, C.; Simon, S.T.; Bendstrup, E.; Prentice, W.; Johnson, M.J.; Currow, D.C.; et al. Managing the supportive care needs of those affected by COVID-19. Eur. Respir. J. 2020, 55, 2000815. [CrossRef]

84. Panigrahy, D.; Gilligan, M.M.; Huang, S.; Gartung, A.; Cortés-Puch, I.; Sime, P.J.; Phipps, R.P.; Serhan, C.N.; Hammock, B.D. Inflammation resolution: A dual-pronged approach to averting cytokine storms in COVID-19? Cancer Metastasis Rev. 2020, 39, 337-340. [CrossRef] [PubMed]

85. Chen, W. Promise and challenges in the development of COVID-19 vaccines. Hum. Vaccines Immunother. 2020, 1-5. [CrossRef]

86. Goel, N.A.; Alam, A.A.; Eggert, E.M.; Acharya, S. Design and development of a customizable telemedicine platform for improving access to healthcare for underserved populations. In Proceedings of the 2017 39th Annual International Conference of the IEEE Engineering in Medicine and Biology Society (EMBC), Seogwipo, Korea, 11-15 July 2017; IEEE: Piscataway, NJ, USA, 2017; pp. 2658-2661. [CrossRef]

87. Ramirez, A.V.; Ojeaga, M.; Espinoza, V.; Hensler, B.; Honrubia, V. Telemedicine in minority and socioeconomically disadvantaged communities amidst COVID-19 pandemic. Otolaryngol. Neck Surg. 2020. [CrossRef] [PubMed]

88. Ryan, C.; Kushalnagar, P. Towards health equity: Deaf adults' engagement in social e-health activities and e-communication with health care providers. J. Heal. Commun. 2018, 23, 836-841. [CrossRef] [PubMed]

89. Senjam, S.S. Impact of COVID-19 pandemic on people living with visual disability. Indian J. Ophthalmol. 2020, 68, 1367. [CrossRef]

90. Chang, Y.-W.; Hsu, P.-Y.; Wang, Y.; Chang, P.-Y. Integration of online and offline health services: The role of doctor-patient online interaction. Patient Educ. Couns. 2019, 102, 1905-1910. [CrossRef]

91. Rosen, C.B.; Joffe, S.; Kelz, R.R. COVID-19 moves medicine into a virtual space. Ann. Surg. 2020, $272,159$. [CrossRef]

92. Gordon, H.S.; Solanki, P.; Bokhour, B.G.; Gopal, R.K. I'm not feeling like i'm part of the conversation patients' perspectives on communicating in clinical video telehealth visits. J. Gen. Intern. Med. 2020, 35, 1751-1758. [CrossRef]

93. Hollander, J.E.; Carr, B.G. Virtually perfect? telemedicine for Covid-19. N. Engl. J. Med. 2020, 382, 1679-1681. [CrossRef] [PubMed]

94. Mann, D.; Chen, J.; Chunara, R.; Testa, P.A.; Nov, O. COVID-19 transforms health care through telemedicine: Evidence from the field. J. Am. Med. Inform. Assoc. 2020, 27, 1132-1135. [CrossRef] [PubMed]

95. Ratwani, R.M.; Brennan, D.; Sheahan, W.; Fong, A.; Adams, K.; Gordon, A.; Calabrese, M.; Hwang, E.; Smith, M.; Booker, E. A descriptive analysis of an on-demand telehealth approach for remote COVID-19 patient screening. J. Telemed. Telecare 2020. [CrossRef] [PubMed]

(C) 2020 by the authors. Licensee MDPI, Basel, Switzerland. This article is an open access article distributed under the terms and conditions of the Creative Commons Attribution (CC BY) license (http://creativecommons.org/licenses/by/4.0/). 